\title{
Jalan Panjang RUU MHA Memperoleh Pengakuan
}

\author{
Oleh: Pardomuan Gultom
}

(Dimuat di Koran ANALISA, edisi Jumat 30 April 2021 dengan link e-paper:

https://analisadaily.com/e-paper/2021-04-30/files/assets/basic-html/index.html\#12)

“Ubi Societas Ibi Ius, di mana ada masyarakat, di situ ada hukum.” Demikian adagium yang pernah diungkapkan Marcus Tullius Cicero, seorang ahli hukum Romawi yang hidup antara 106-43 SM. Ungkapan ini bermakna bahwa hukum lahir dan terbentuk akibat dari pola interaksi sesama anggota masyarakat yang mengandung nilai-nilai dan hubungannya terhadap alam dimana ia tinggal serta melangsungkan kehidupan secara turun-temurun hingga pada akhirnya membentuk kebudayaan.

Dalam konteks masyarakat adat, hukum yang terbentuk adalah hukum adat, yang mendasarkan sistem kehidupannya pada adat-istiadat yang mencakup larangan dan kebiasaan yang telah diwariskan secara turun-temurun dan berkelanjutan. Pentingnya pengakuan terhadap masyarakat adat dalam bentuk undang-undang bukan saja dapat memberikan jaminan kepastian hukum kepada masyarakat adat, tetapi lebih jauh dari itu, yakni menjamin tercapainya keadilan bagi masyarakat adat.

\section{Legal Standing}

Jika ditarik ke belakang, eksistensi Hukum Adat telah menjadi pembahasan dalam pembentukan UUD 1945 saat sidang BPUPKI dan PPKI oleh Soepomo dan Muhammad Yamin, yang mengemukakan pendapat agar hukum adat mendapat pengakuan di dalam konstitusi yang akan dibentuk. Soepomo menyampaikan bahwa hak asal usul dalam daerahdaerah yang bersifat istimewa harus diperingati juga. (Bahar, 2008). Demikian juga dengan Muhammad Yamin menyampaikan bahwa kesanggupan dan kecakapan bangsa Indonesia dalam mengurus tata negara dan hak atas tanah sudah muncul beribu-ribu tahun yang lalu (Taqwaddin, 2010).

Setidaknya, terdapat 27 ketentuan yang telah mengatur eksistensi masyarakat adat di Indonesia selain Pasal 18B ayat (1) dan Pasal 28I ayat (3) Undang-Undang Dasar 1945, yakni: Pasal 4 Tap MPR No. IX Tahun 2001 tentang Pembaruan Agraria dan Pengelolaan Sumber Daya Alam, Pasal 5 dan Pasal 6 UU No. 5 Tahun 1960 tentang Pokok-Pokok Agraria, Pasal 8 UU No. 5 Tahun 1994 tentang Pengesahan Konvensi Internasional Mengenai 
Keanekaragaman Hayati, Pasal 6 UU No. 39 Tahun 1999 tentang Hak Asasi Manusia, Pasal 6 ayat (2) UU No. 7 Tahun 2004 tentang Sumber Daya Air, Pasal 9 ayat (2) UU No. 18 Tahun 2004 tentang Perkebunan, Pasal 67 ayat (1) UU. 41 Tahun 1999 tentang Kehutanan, Pasal 25 UU No. 23 Tahun 2006 tentang Administrasi Kependudukan, Pasal 4 UU No. 26 Tahun 2007 tentang Penataan Ruang, Pasal 1 angka 33 UU No. 1 Tahun 2014 Perubahan Atas UU No. 27 Tahun 2007 tentang Pengelolaan Wilayah Pesisir dan Pulau-Pulau Kecil, Pasal 1 angka 43 UU No. 23 Tahun 2014 tentang Pemerintahan Daerah, Pasal 67 UU No. 4 Tahun 2009 tentang Pertambangan Minerba, Pasal 1 angka 31 dan Pasal 63 UU No. 32 Tahun 2004 tentang Perlindungan dan Pengelolaan Lingkungan Hidup, Penjelasan Pasal 40 UU No. 2 Tahun 2012 tentang Pengadaan Tanah bagi Pembangunan untuk Kepentingan Umum, Pasal 1 huruf p dan Pasal 1 huruf r UU No. 21 Tahun 2001 tentang Otonomi Khusus bagi Provinsi Papua, Pasal 142 dan Pasal 149 ayat (1) UU No. 11 Tahun 2006 tentang Pemerintahan Aceh, dan Pasal 1 angka 1, Pasal 96, dan Pasal 97 UU No. 6 Tahun 2014 tentang Desa.

\section{Pengakuan Internasional}

Secara global, masyarakat adat atau biasa disebut indigenous peoples telah mendapat pengakuan. Hal ini terlihat dari beberapa kesepakatan internasional atas eksistensi masyarakat adat, yakni Convention of International Labor Organisation Concerning Indigeneous and Tribal People in Independent Countries (1989), Deklarasi CariOca tentang Hak-Hak Masyarakat Adat (1992), Deklarasi Bumi Rio de Janairo (1992), Declaration on the Right of Asian Indigenous Tribal People Chiang Mai (1993), De Vienna Declaration and Programme Action yang dirumuskan oleh United Nations World Conference on Human Rights (1993). Saat ini istilah indigenous people semakin resmi digunakan sejak lahirnya Deklarasi PBB tentang Hak-Hak Masyarakat Adat (United Nation Declaration on the Rights of Indegenous People) pada tahun 2007.

\section{Dinamika Legislasi}

Sejak tahun 2007, usulan untuk membentuk undang-undang yang khusus memberikan perlindungan dan pemenuhan hak konstitusional bagi Masyarakat Hukum Adat di Indonesia pernah masuk dalam Program Legislasi Nasional (Prolegnas). Begitu juga tahun 2014 dan 2017. Namun nasib Rancangan Undang-Undang (RUU) Masyarakat Hukum Adat belum mendapat kepastian hukum. 
Di tahun 2018 yang lalu, RUU ini kembali masuk dalam Prolegnas prioritas DPR. Pada tanggal 9 Maret 2018, Presiden Joko Widodo pernah mengeluarkan Surat Perintah Presiden (Surpres) melalui Kementerian Sekretariat Negara No B-186 yang mengatur tentang pembentukan tim pemerintah yang akan membahas RUU Masyarakat Adat bersama DPR (Mongabay, 13/12/2019). Dan pada 14 Januari 2021 yang lalu, dikeketahui bahwa RUU ini tetap masuk dalam Prolegnas prioritas yang ditetapkan oleh Badan Legislasi (Baleg) DPR dalam rapat kerja bersama Menkumham dan DPD RI (Jawapos, 23/3).

\section{Problem Pendataan}

Menurut laporan UN Permanen Forum on Indigenous Issue (2014) memperkirakan jumlah indigenous peoples sekitar 370 juta jiwa. Dan 2/3 dari jumlah tersebut tinggal di Asia. (Arizona, 2014). Pada tahun 2000, Departemen Sosial mencatat kelompok Komunitas Adat Terpencil (KAT) sebanyak 242.514 kepala keluarga (KK) atau 1.212.575 jiwa yang tersebar di 18 provinsi. Populasi kebanyakan terdapat di Papua, Kalimantan, Sumatera, dan Sulawesi. Pada tahun 2006, Departemen Sosial melakukan pemetaan kembali yang kemudian dimutakhirkan pada tahun 2008 dan menghasilkan jumlah populasi KAT sebanyak 229.479 KK. Kementerian Negara Percepatan Pembangunan Daerah Tertinggal menyebutkan jumlah penduduk yang tinggal di desa hutan mencapai 33.512.845 jiwa. Sementara menurut Aliansi Masyarakat Adat Nusantara (AMAN), jumlah masyarakat adat di Indonesia sebanyak 80 juta jiwa (Cahyaningrum, 2015).

\section{Pengakuan Hutan Adat}

Hingga tahun 2019, pemerintah melalui Kementerian Lingkungan Hidup dan Kehutanan telah menetapkan luas hutan adat sebanyak 34.569 Hektare dari 574.119 luas wilayah indikatif hutan adat (Antaranews, 9/8/2019). Luas hutan adat ini bertambah dari 17.243 Hektar di tahun 2018. Namun luas wilayah indikatif hutan adat versi Kementerian LHK ini masih jauh dari usulan Aliansi Masyarakat Adat Nusantara (AMAN), yakni 9,6 juta hektare.

Menurut AMAN, Indonesia membutuhkan waktu hampir 200 tahun untuk mengakui jumlah minimum hutan adat di Indonesia jika menggunakan percepatan pengakuan hutan adat versi Kementerian LHK (RMI, 2019).

Pengakuan negara terhadap keberadaan Masyarakat Hukum Adat merupakan bentuk kewajiban negara di dalam pemenuhan hak asasi warga secara legal formal yang di dalamnya 
mencakup perlindungan Masyarakat Hukum Adat dari ancaman ekspansi modal lewat korporasi perkebunan dan kehutanan. Perlindungan yang dimaksud disini mencakup aspek wilayah adat, pranata adat, lembaga adat, dan tradisi adat. Dengan demikian, dibutuhkan undang-undang sebagai jaminan perlindungan dan pemenuhan hak-hak Masyarakat Hukum Adat.

Di sisi lain, konflik tenurial antara Masyarakat Hukum Adat dengan korporasi swasta, kepentingan perusahaan yang dikelola oleh pemerintah, maupun perseorangan telah terjadi sejak Indonesia belum ada hingga kini. Pertanyaannya, bilakah negara, melalui UndangUndang Masyarakat Hukum Adat, bersedia mengeluarkan areal-areal milik masyarakat adat yang sebelumnya pernah diklaim lewat hak istimewa (perizinan) yang diterbitkan bagi korporasi swasta maupun perusahaan yang dikelola pemerintah, seperti izin Hak Guna Usaha (HGU)?

Selain itu, proses pengakuan terhadap masyarakat hukum adat tidak diatur secara memadai, tumpang tindih, dan sektoral. Pasal 67 UU No. 41 Tahun 1999 tentang Kehutanan, prosedur pengukuhan keberadaan masyarakat adat melalui Perda. Sementara, dalam Permendagri No. 52 Tahun 2014 tentang Tatacara Pengakuan dan Perlindungan Masyarakat Hukum Adat mengatur penetapan Masyarakat Hukum Adat melalui Keputusan Kepala Daerah, yakni Bupati/Walikota atau Gubernur. Hal yang sama juga terdapat dalam Permen ATR No. 10 Tahun 2016 tentang Tatacara Penetapan Hak Komunal atas Tanah Masyarakat Hukum Adat dan Masyarakat yang berada dalam Kawasan Tertentu ditetapkan melalui Keputusan Kepada Daerah.

Terkait dengan proses dalam memperoleh pengakuan ini, masyarakat adat akan berbenturan dengan mental pejabat dan birokrasi mulai dari tingkat daerah hingga pusat. Lagi-lagi hal ini kembali kepada komitmen politik (political will) Kepala Daerah beserta legislatif daerah dalam membuat prioritas kebijakan yang berpihak kepada Masyarakat Hukum Adat di wilayah kekuasaannya, mulai dari pendataan hingga penerbitan keputusan pengakuan terhadap Masyarakat Hukum Adat.

Kepala daerah harus mampu menggerakkan mesin birokrasi di wilayah yang termasuk dalam Wilayah Adat untuk mempercepat proses pengakuan Masyarakat Hukum Adat agar efektif, efisien, tidak bertele-tele, serta tidak diskriminatif. Istilah "jemput bola" mungkin lebih tepat 
digunakan dalam upaya melakukan inventarisasi komunitas-komunitas Masyarakat Hukum Adat, pemetaan Wilayah Adat, hingga penetapan tapal batas yang merupakan wilayah yang dimanfaatkan oleh masyarakat adat.

Kiranya pengakuan negara terhadap Masyarakat Hukum Adat dalam bentuk undang-undang nantinya tidak menjadi beban bagi masyarakat adat dalam memperoleh perlindungan dan pemenuhan hak-haknya. Dan semoga RUU Masyarakat Hukum Adat mendapat pengesahan yang tidak terlalu lama dan menjadi solusi atas problem yang selama ini dihadapi masyarakat adat.

*Penulis adalah Mahasiswa konversi Sekolah Tinggi Ilmu Hukum (STIH) Graha Kirana/Alumnus Departemen Ilmu Politik FISIP USU 